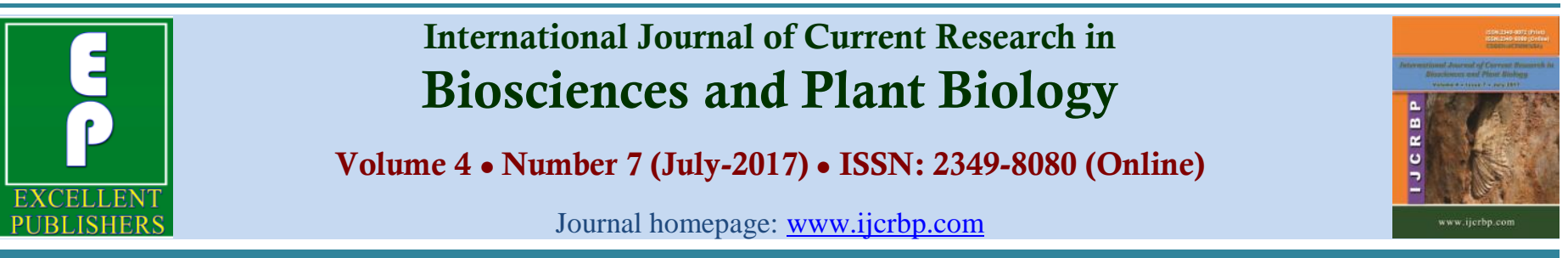

\title{
Inhibition Effects of Elaeis oleifera (Arecaceae) and Launaea taraxacifolia (Asteraceae) on Two Genotypes of Anopheles gambiae Larvae
}

\author{
Ahouansou C. Ayidé ${ }^{1,2 *}$, Fagbohoun Louis ${ }^{2}$, Mèdégan Fagla Sèdami ${ }^{1}$, Houngbèmè G. Alban ${ }^{2}$, \\ Kotchoni Siméon ${ }^{3}$ and Gbaguidi A. Fernand ${ }^{1,2}$
}

\author{
${ }^{1}$ Laboratory of Chemistry and Organic Pharmaceutical / Faculty of Health Sciences / University of Abomey-Calavi, 01 BP 188 \\ Cotonou/Benin \\ ${ }^{2}$ Pharmacognosy Laboratory / Technical and Scientific Research Beninese Center, 01 BP 06 Oganla Porto-Novo/Benin \\ ${ }^{3}$ Center for Computational and Integrative Biology, Rutgers, the State University of New Jersey 315 Penn Street, Science Building, \\ Camden, NJ 08102-1411
}

\section{*Corresponding author.}

\section{Abstract}

The management of breeding sites is one of the preventive measures against malaria. However, in view of the environmental damage caused by the various chemical insecticides used for this purpose and especially the resistances developed by Anopheles gambiae (the main vector) with respect to these synthetic chemical compounds, we have proposed implementing of extracts plants. Thus, organic solvents with a gradient of polarities such as $n$ hexane, dichloromethane and methanol-water were used to extract the phytochemical compounds present in the leaves of Elaeis oleifera and Launaea taraxacifolia. The three different extracts obtained for each plant were tested on 3rd stage larvae from two genotypes of Anopheles gambiae: the Kisumu strain of Kenyan origin and the wild strain from the breeding sites of Cotonou. Phytochemical analysis revealed that in addition to tannins, flavonoids, anthocyanins, leuco-anthocyanins and triterpenes which are present in both plants, Elaeis oleifera also contains mucilages and alkaloids. The hydro-methanolic extracts were found to be the most active on the two origins of larvae with lethal concentrations $\mathrm{LC}_{50}$ of $448.01 \mathrm{ppm}$ in $24 \mathrm{hrs}$ and $51.38 \mathrm{ppm}$ in $48 \mathrm{hrs}$ of exposure for the Kisumu strain; 4199.63 ppm and $1456.44 \mathrm{ppm}$ in $24 \mathrm{hrs}$ and $48 \mathrm{hrs}$ respectively for the wild population for Elaeis oleifera. In addition, Launaea taraxacifolia appeared much more interesting and displayed almost identical activities on the two larval origins with $\mathrm{LC}_{50}$ of $182.68 \mathrm{ppm}$ and $135.13 \mathrm{ppm}$ respectively in $24 \mathrm{hrs}$ and $48 \mathrm{hrs}$ for Kisumu larvae and $157.36 \mathrm{ppm}$ in $24 \mathrm{hrs}$ then 116.88 ppm in 48 hrs for wild larvae. It is therefore concluded that Launaea taraxacifolia can be used for bio-larvicide production in integrated malaria vector control.
\end{abstract}

\section{Introduction}

Vector control is one of the main prevention measures for malaria in the absence of a vaccine. In addition to the

\section{Article Info}

Accepted: 27 June 2017

Available Online: 06 July 2017

\section{Keywords}

Anopheles gambiae

Elaeis oleifera

Environment

Launaea taraxacifolia

Malarial vector two widely applicable basic methods for controlling the vectors of the disease, which are long-lasting insecticidal nets and indoor spraying, the management of breeding sites appears today as a complementary 
measure (Fillinger et al., 2009; OMS, 2016). This method of reduction of the number of mosquito larvae and nymphs results in larvicidal treatments, which involve the regular application of insecticides, often of synthetic chemical nature, to water bodies. However, it could induce multiple dysfunctions of aquatic and terrestrial ecosystems through bioaccumulation and appearance of resistance of the target vectors, in particular Anopheles gambiae (Djogbenou et al., 2011; Edi et al., 2012; Nwane et al., 2013) and then considerably reduce the effectiveness of the treatment. Although the development of resistance of mosquitoes has not yet been detected with bio-insecticides of microbial origin and for rough use such as Bacillus sphaericus and Bacillus thuringiensis var. israelensis (Becker, 1998), it is important to broaden this spectrum of new biochemical insecticides in order to be ready to respond to all eventualities, as well as to have a system of effective control of these populations of vectors. The use of naturally occurring insecticides based on active plant extracts applicable to mosquito larvae is necessary for the control of malaria vectors (Chougourou et al., 2012).

Several studies have pointed to this direction with the aim of searching for phytomolecules which can serve as a basis for the formulation of bio-larvicides. Hyptis suaveolens has been shown to inhibit the larvae of Culex quinquefaciatus, a vector of lymphatic filariasis (Murugesan et al., 2015). Ficus benghalensis acts on the larvae of Aedes aegypti and Anopheles stephensi (Govindarajan, 2010a). In addition, recent studies in Benin have investigated the activities of polyphenol-rich plants on larvae of parasitic insects such as Launaea taraxacifolia on Anopheles gambiae larvae (Ahouansou et al., 2016) and Elaeis oleifera on the larvae of Coelaenomenodera lameensis. Elaeis oleifera is a species of palm tree that is resistant to the attacks of Coelaenomenodera lameensis larvae among the various oil palm genotypes due to its rich polyphenolic compounds (Fagbohoun et al., 2015). In addition, Launaea taraxacifolia is known and domesticated in all West African countries (Adebisi, 2004). Its leaves eaten fresh in salad or cooked as sauce (Koukoui et al., 2015), are nutritionally rich in vitamins, proteins, minerals, essential fatty acids, fiber and flavonoids (Adinortey et al., 2012; Dickson et al., 2012) and are widely used as an infusion for the treatment of several diseases such as blood pressure regulation, dyslipidemia, management of cholesterol blood levels, antioxidant properties and viral infections (Arawande et al., 2013; Dansi et al., 2012;
Owoeye et al., 2015). In this connection, the objective of this work has been framed to evaluate the insecticidal potential of Launaea taraxacifolia and Elaeis oleifera on larvae of Anopheles gambiae from different origins in a comparative study of plants with larvicidal activities.

\section{Materials and methods}

\section{Collection of larvae, plants and extractions}

Bio-tests were carried out on two categories of larvae of Anopheles gambiae: wild larvae collected in breeding sites to Cotonou according to the morphological and behavioral characteristics of the larvae using taxonomic identification keys (Gillies and Coetzee, 1987) and Kisumu larvae of Kenyan origin obtained at the Center for Entomological Research of Cotonou (CREC). The latter have been maintained in breeding in the CREC laboratory for several years and their sensitivity is regularly checked. The leaflets of Elaeis oleifera were harvested from the plantations of the Benin Agricultural Research Institute (INRAB) in the commune of Pobè while the aerial parts of Launaea taraxacifolia were harvested from corn fields at Comé in the southern part of Benin. After collection, the samples were transported to the laboratory and then dried at $16^{\circ} \mathrm{C}$ before being ground and reduced to powder. In a first step, the extractions were carried out with three solvents of different polarity: $n$-hexane, dichloromethane and methanol in order to obtain the crude extracts. To $100 \mathrm{~g}$ of powder from each plant sample, was added $500 \mathrm{~mL}$ of $n$-hexane. The mixture was homogenized, then kept under continuous stirring for $24 \mathrm{hrs}$, and then filtered and evaporated to dryness using a rotary evaporator (Heidolph Laborota 4000 efficient). The same operation is carried out for dichloromethane. As to the third extraction, we used the methanol-water mixture (70:30; $\mathrm{v} / \mathrm{v})$ with $0.5 \%$ of formic acid following the same process described above. The operations were repeated three times and the dry residue obtained at each operation was weighed out to determine the average yield of extraction.

\section{Phytochemical analyzes}

The different chemical groups were found in the samples of E. Oleifera and L. taraxacifolia using the classical method of Houghton and Raman (Houghton and Roman, 1998), used routinely and very recently by Fagbohoun et al. (2014 and 2015). Thus the Mayer and Dragendorff tests are used for alkaloids, the Fehling test 
for reducing compounds and glycosides, the Liebermann-Burchard test for triterpenoids and steroids, the Frothy test for saponins, the Shinoda tests and sodium hydroxide for flavonoids, the ferric chloride test for tannins, the Guignard test for free cyanogenic derivatives and the Borntrager test for anthraquinones.

\section{Biological tests on Anopheles gambiae}

The bioassays were carried out on larvae of Anopheles gambiae according to the WHO standard protocol for the larval susceptibility tests against insecticides used in control campaigns with a slight modification in accordance to our conditions (WHO, 2005). Kisumu larvae were treated with solutions of extracts of concentrations ranging from 62.5 to $2000 \mathrm{ppm}$ prepared from each type of extract with 2\% DMSO (Dimethyl sulfoxide); while wild larvae were subjected to extract solutions with concentrations ranging from 62.5 to $15000 \mathrm{ppm}$ when appropriate. The tests were carried out in transparent cups $5 \mathrm{~cm}$ in diameter, each containing $100 \mathrm{ml}$ of solution and 20 larvae of Anopheles gambiae in the third stage of the same category. The same number of larvae was placed in another control cup containing only $100 \mathrm{~mL}$ of $2 \%$ aqueous of dimethyl sulphoxide (DMSO). For each concentration of the extracts as well as for the control, three replicates were made. Larval behavior, by counting the number of survivors, was monitored for $48 \mathrm{hrs}$ and lethal concentrations $\left(\mathrm{LC}_{50}\right)$ were determined every $24 \mathrm{hrs}$. Indeed, dead larvae were considered immobile even when in contact of a needle and also those that wre moribund.

\section{Statistical analyses}

The analysis of the data is carried out using the SPSS 21.0 statistical software at the risk of $5 \%(p<0.05)$ in order to obtain the average mortality rate of Anopheles larvae according to the doses applied and to extract the lethal concentrations $\left(\mathrm{LC}_{50}\right)$.

\section{Results}

\section{Phytochemical Screening}

Table 1 presents the results obtained after the detection of 17 chemical groups in the two plants studied. In addition to tannins, flavonoids, anthocyanins and leucoanthocyanins, as well as terpenes found in both plants, Elaeis oleifera also contains mucilages and alkaloids.

Table 1. Plants phytochemical Screening

\begin{tabular}{lll}
\hline Compounds & $\begin{array}{l}\text { Launaea } \\
\text { taraxacifolia }\end{array}$ & $\begin{array}{l}\text { Elaeis } \\
\text { oleifera }\end{array}$ \\
\hline Tannins & + & + \\
Catechin tannins & + & + \\
Galic tannins & + & + \\
Flavonoids & + & + \\
Anthocyanins & + & + \\
Leuco-anthocyanins & + & + \\
Quinone derivatives & - & - \\
Saponosides & - & - \\
Triterpenes & + & + \\
Steroïds & - & - \\
Cyanogenic & - & - \\
compounds & & \\
Mucilages & - & + \\
Reducing compounds & - & - \\
Coumarins & - & - \\
Free anthracene & - & - \\
O-glycosides & - & - \\
C-glycosides & - & - \\
Cardiac glycosides & - & - \\
Alkaloids & - & + \\
\hline + = Present; - = Absent. & & \\
\hline
\end{tabular}

\section{Extraction yields}

The yields of crude extracts of Launaea taraxacifolia and Elaeis oleifera to $n$-hexane, dichloromethane and methanol-water are reported in Table 2.

Table 2. Extraction yields of plants in different solvents.

\begin{tabular}{lllllll}
\hline Solvents & n-Hexane & \multicolumn{3}{c}{ Dichloromethane } & \multicolumn{2}{c}{ Methanol/water } \\
\hline Plants & $\begin{array}{l}\text { Launaea } \\
\text { taraxacifolia }\end{array}$ & $\begin{array}{l}\text { Elaeis } \\
\text { oleifera }\end{array}$ & $\begin{array}{l}\text { Launaea } \\
\text { taraxacifolia }\end{array}$ & $\begin{array}{l}\text { Elaeis } \\
\text { oleifera }\end{array}$ & $\begin{array}{l}\text { Launaea } \\
\text { taraxacifolia }\end{array}$ & $\begin{array}{l}\text { Elaeis } \\
\text { oleifera }\end{array}$ \\
Yield (\%) & $2.05 \pm 0.11$ & $3.41 \pm 0.17$ & $5.51 \pm 0.23$ & $4.03 \pm 0.28$ & $18.89 \pm 1.11$ & $14.48 \pm 1.03$ \\
\hline
\end{tabular}

Table 2 shows that the hydro-methanolic mixture is the solvent which produced the greatest quantity of extracts obtained at the level of the two plants with yields of $18.89 \%$ and $14.48 \%$ respectively for Launaea
Taraxacifolia and Elaeis oleifera. Indeed, these results justify the polar nature of the predominant compounds in both plants. The extract yields of other solvents of the plants were found to be $<6 \%$. 


\section{Biological screening of crude extracts on larvae of Anopheles gambiae}

Of the three extracts used for the anti-larval tests with Elaeis oleifera, the hydro-methanolic extract is the one which showed notably a fairly interesting inhibitory activity on the Kisumu larvae (Table 3). Indeed, although no larva died within $24 \mathrm{hrs}$ at 62.5 $\mathrm{ppm}$, half of the tested larvae population died at 62.5 ppm after $48 \mathrm{hrs}$ of exposure and a 100\% mortality rate was obtained at $500 \mathrm{ppm}$ in extract concentration.

Table 3. Mortality rate (\%) of Kisumu larvae with extracts of Elaeis oleifera and Launaea taraxacifolia.

\begin{tabular}{llllllll}
\hline \multirow{2}{*}{ Plant } & Conc. in & \multicolumn{2}{l}{ Dichloromethane } & \multicolumn{2}{l}{ Methanol-water } & \multicolumn{2}{l}{$\boldsymbol{n}$-Hexane } \\
\cline { 2 - 7 } & $\mathbf{p p m}$ & $\mathbf{2 4} \mathbf{~ h r s}$ & $\mathbf{4 8} \mathbf{~ h r s}$ & $\mathbf{2 4} \mathbf{~ h r s}$ & $\mathbf{4 8} \mathbf{~ h r s}$ & $\mathbf{2 4} \mathbf{~ h r s}$ & $\mathbf{4 8} \mathbf{~ h r s}$ \\
\hline Elaeis oleifera & 2000 & $70.00 \pm 2.887$ & $80.00 \pm 2.887$ & $100 \pm 0.00$ & $100 \pm 0.00$ & $100 \pm 0.00$ & $100 \pm 0.00$ \\
& 1000 & $51.66 \pm 1.667$ & $65.00 \pm 2.887$ & $93.33 \pm 1.667$ & $100 \pm 0.00$ & $100 \pm 0.00$ & $100 \pm 0.00$ \\
& 500 & $10.00 \pm 0.00$ & $26.66 \pm 1.667$ & $65.00 \pm 2.887$ & $100 \pm 0.00$ & $50.00 \pm 2.887$ & $68.33 \pm 1.667$ \\
& 250 & 0.00 & $10.00 \pm 2.887$ & $6.66 \pm 1.667$ & $80.00 \pm 1.667$ & $13.33 \pm 3.333$ & $26.67 \pm 1.667$ \\
& 125 & 0.00 & 0.00 & 0.00 & $71.66 \pm 1.667$ & 0.00 & 0.00 \\
& 62.5 & 0.00 & 0.00 & 0.00 & $50.00 \pm 2.887$ & 0.00 & 0.00 \\
Launaea & Control & 0.00 & 0.00 & 0.00 & 0.00 & 0.00 & 0.00 \\
taraxacifolia & 2000 & $31.66 \pm 1.667$ & $51.66 \pm 1.667$ & $100 \pm 0.00$ & $100 \pm 0.00$ & $100 \pm 0.00$ & $100 \pm 0.00$ \\
& 1000 & $10.00 \pm 0.00$ & $26.66 \pm 1.667$ & $100 \pm 0.00$ & $100 \pm 0.00$ & $100 \pm 0.00$ & $100 \pm 0.00$ \\
& 500 & 0.00 & $10.00 \pm 0.00$ & $100 \pm 0.00$ & $100 \pm 0.00$ & $25.00 \pm 2.887$ & $41.67 \pm 4.410$ \\
& 250 & 0.00 & 0.00 & $75.00 \pm 2.887$ & $81.66 \pm 1.667$ & $5.00 \pm 0.00$ & $13.33 \pm 1.667$ \\
& 125 & 0.00 & 0.00 & $21.66 \pm 1.667$ & $30.00 \pm 2.887$ & $1.67 \pm 1.667$ & $6.67 \pm 1.667$ \\
& 62.5 & 0.00 & 0.00 & 0.00 & 0.00 & $1.67 \pm 1.667$ & $5.00 \pm 0.00$ \\
& Control & 0.00 & 0.00 & 0.00 & 0.00 & 0.00 & 0.00 \\
\hline
\end{tabular}

Conc : Concentration ; Larvicidal activities of Elaeis oleifera and Launaea taraxacifolia extracts on Kisumu larvae.

Table 4. Mortality rate (\%) of wild larvae with extracts of Elaeis oleifera and Launaea taraxacifolia.

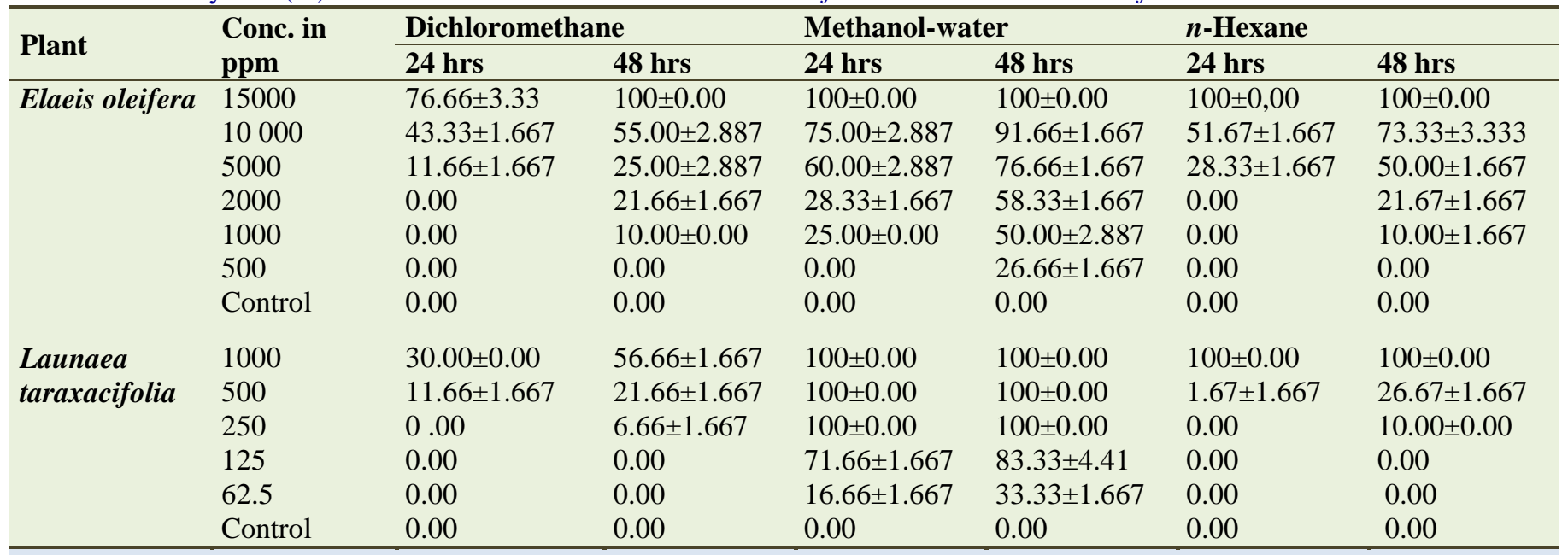

Conc. : Concentration; Larvicidal activities of Elaeis oleifera and Launaea taraxacifolia extracts on wild larvae

In addition to the wild larvae, the hydro-methanolic extract remains the most active but at very high concentrations; it is necessary to reach $15000 \mathrm{ppm}$ before obtaining $100 \%$ mortality at $24 \mathrm{hrs}$ (Table 4). These same observations were made at the level of Launaea taraxacifolia with a few differences. The hydro-methanolic extract is also the most active with a mortality rate of $100 \%$ to $500 \mathrm{ppm}$ after $24 \mathrm{hrs}$ of contact with Kisumu larvae (Table 3) and 250 ppm for wild larvae at the same exposure time (Table 4). Note that the control leads to $2 \%$ DMSO has no inhibitory effect on the larvae of strain Kisumu as wild, which continue to live during the $48 \mathrm{hrs}$ of experience. Lethal concentrations responsible for $50 \%$ mortality of Kisumu and wild larvae in $24 \mathrm{hrs}$ and $48 \mathrm{hrs}$ are summarized in Table 5. At $24 \mathrm{hrs}$, the $\mathrm{LC}_{50}(448.01 \mathrm{ppm})$ of the hydromethanolic extract on the Kisumu larvae is followed by close to that of the $n$-hexane extract (529.36 ppm) 
followed by that of the dichloromethane extract (1161.18 ppm) with Elaeis oleifera. This tendency is maintained in $48 \mathrm{~h}$ of exposure, this time with a $\mathrm{LC}_{50}$ $(51.38 \mathrm{ppm})$ which is quite remarkable for the hydromethanolic extract.

Conversely, Elaeis oleifera has a very moderate inhibitory effect on wild larvae, as evidenced by the doses inducing 50\% mortality of the larvae: 4199.63 and
1456.44 ppm obtained in $24 \mathrm{hrs}$ and $48 \mathrm{hrs}$ respectively with the hydro-methanolic extract. It should be noted that the order of inhibition of the three extracts on the Kisumu and wild larvae for Elaeis oleifera is also maintained at Launaea taraxacifolia. On the other hand, the $\mathrm{LC}_{50}$ obtained with the hydro-methanolic extract is almost the same: 157.36 and $116.88 \mathrm{ppm}$ respectively in $24 \mathrm{hrs}$ and $48 \mathrm{hrs}$ on the wild larvae compared to those obtained in the Kisumu larvae (182.68 and 135.13 ppm).

Table 5. $\mathrm{LC}_{50}$ values in ppm of extracts tested on larvae.

\begin{tabular}{llllll}
\hline \multirow{2}{*}{ Plant } & Extracts & $\mathbf{L C}_{\mathbf{5 0}}($ Kisumu) & \multicolumn{2}{c}{ LC $_{\mathbf{5 0}}$ (wild) } \\
\cline { 3 - 6 } Elaeis oleifera & $\mathbf{2 4} \mathbf{h r s}$ & $\mathbf{4 8} \mathbf{~ h r s}$ & $\mathbf{2 4} \mathbf{~ h r s}$ & $\mathbf{4 8} \mathbf{~ h r s}$ \\
& Dichloromethane & 1161.18 & 790.63 & 10980.60 & 6817.71 \\
& Methanol-water & 448.01 & 51.38 & 4199.63 & 1456.44 \\
Launaea taraxacifolia & n-Hexane & 529.36 & 411.42 & 8776.49 & 6367.31 \\
& Dichloromethane & 2675.62 & 1951.75 & 2412.99 & 1833.65 \\
& Methanol-water & 182.68 & 135.13 & 157.36 & 116.88 \\
& $n$-Hexane & 729.08 & 614.94 & 834.23 & 747.94 \\
\hline
\end{tabular}

$p<0.05$ significant level; Concentrations causing mortality of half of larvae.

\section{Discussion}

The phenomenon of resistance to insecticides developed by Anopheles gambiae has prompted the search for phyto-larvicides which are beneficial to the environment and will target mosquitoes that are resistant to chemical insecticides. Indeed, although the integrated control program for Anopheles gambiae proposed by (Coosemans et al., 1992), which includes the use of deltameter-treated mosquito nets and repellent and/or intra-residential treatments, may have reduced malaria prevalence, these authors had shown that this method did not in any way reduce the density or the burden of the target parasite populations.

In this study we conducted bioassays of different extracts of Launaea taraxacifolia and Elaeis oleifera against wild-type and Kisumu-type $3^{\text {rd }}$ instar mosquito larvae at different concentrations. Our results showed that the mortality rate of the larvae differs according to the concentrations and duration of exposure, whatever the species and the extract used. The lowest $\mathrm{LC}_{50}$ are derived from hydro-methanolic extracts. These results, although somewhat preliminary, reveal the value of the hydro-methanolic extracts of Launaea taraxacifolia and Elaeis oleifera compared to the hexanic and dichloromethanic extracts. Moreover, similar studies carried out by Komalamisra et al. (2005) and Govindarajan (2010a) showed a larvicidal efficacy of the methanolic extract of Rhinacanthus nasutus, Derris elliptica and Ficus benghalensis respectively on larvae of Culex quinquefasciatus, Aedes aegypti and Anopheles stephensi compared to the solvents acetone and benzene. In addition, the highest dry extract yield obtained at the level of the two plants studied comes from the hydro-methanolic solvent. This result is the outgrowth of the presence of a majority of polar chemical groups responsible for the larvicidal activity shown by this extract in both plants compared to the extraction with hexane and dichloromethane. Indeed, the characterization of the major chemical groups in the two species Launaea taraxacifolia and Elaeis oleifera, revealed the presence of tannins, flavonoids, anthocyanins and leuco-anthocyanins which are exclusively polyphenols and triterpenes accessorily within both plants. Elaeis oleifera also contains mucilages and alkaloids that are not found in Launaea taraxacifolia. These results are in line with those obtained in the previous work carried out by Fagbohoun et al. (2015) and Koukoui et al. (2015).

From the set of the presented results, a first classification of the toxic efficacy of the extracts tested can be demonstrated; thus, the hydro-methanolic extract of Launaea taraxacifolia has an inhibitory effect on the two genotypes of larvae of Anopheles gambiae studied, whereas its Elaeis oleifera counterpart is only active on Kisumu larvae and has a very moderate inhibitory effect on the wild larvae. This tolerance of wild larvae to E. oleifera can be related to 
the compounds of the alkaloid group characterized in this plant. Similar studies have been carried out on two species of Senecio: S. jacobaeae and S. vulgaris, the leaves of which contain a series of pyrrolizidinic alkaloids (Harry et al., 1994), have shown that larvae of certain lepidoptera such as Arctia caja and Tyria jacobaeae have developed a certain accommodation in the face of alkaloid toxins and managed to accomplish their complete development. It is possible that, despite the presence of polar compounds in this latter, tolerance to alkaloids, would contribute to the resistance observed by Anopheles gambiae in the presence of certain chemical insecticides from the group of organophosphates, pyrethroids and carbamates (Djogbenou et al., 2011; Edi et al., 2012; Nwane et al., 2013). Moreover, it could also be explained by a differential presence in structure and quantity of the larvicidal substances incriminated in the two species studied above.

The alkaloids found in Elaeis oleifera could thus influence the toxicity of active molecules in the wild larvae of An. gambiae. Indeed, at $500 \mathrm{ppm}$ of hydroalcoholic extract, all Kisumu larvae die after $48 \mathrm{~h}$ of exposure, whereas to obtain the same result on the wild larvae, it will be necessary to apply thirty times the previous dose $(15000 \mathrm{ppm})$. This selection of larvicidal activity on two genotypes of the same mosquito species shows that the use of Elaeis oleifera in the formulation of an insecticide against $A n$. gambiae would be somewhat hypothetical. However, this species showed the lowest $\mathrm{LC}_{50}(51.38 \mathrm{ppm})$ of all the bioassays carried out during the $48 \mathrm{hrs}$ of contact with the Kisumu larvae. This potential for inhibition, in line with the resistance of this plant attacks by the larvae of Coelaenomenodera lameensis, an oil palm leafminer, has been demonstrated by Fagbohoun et al. (2015). It is all the more interesting in terms of toxicity to larvae of anopheles Kisumu, as shown by Aouinty et al. (2006), with the lowest $\mathrm{LC}_{50}, 530 \mathrm{ppm}$ and 600 ppm, those of extracts of Tetraclinis articulata and Ricinus communis on mosquitoes of Culex pipiens, Anopheles caspius, Culex longiareolata and Anopheles maculipennis.

Moreover, the hydro-methanolic extract of Launaea taraxacifolia, was more active on both larval categories regardless of the time of exposure, with the only difference that after $48 \mathrm{hrs}$ of exposure of the larvae Kisumu, its $\mathrm{LC}_{50}(135.13 \mathrm{ppm})$ is significantly higher than that obtained with Elaeis oleifera (51.38 ppm). On the whole, we observe that the larvae of the wild population of Anopheles gambiae of Cotonou present approximately the same sensitivity to the larvicidal substances retained by the hydro-methanolic mixture of Launaea taraxacifolia, compared to the Kisumu larvae called "sensitive", with a lethal dose of $116.88 \mathrm{ppm}$. This dose reflects significantly lower toxicity than the methane extract of Sida acuta against mosquito larvae: Anopheles stephensi $\left(\mathrm{LC}_{50}=38.64\right.$ ppm), Aedes aegypti $\left(\mathrm{LC}_{50}=42.08 \mathrm{ppm}\right)$ and Culex quinquefasciatus $\left(\mathrm{LC}_{50}=47.91 \mathrm{ppm}\right)$, with reference to the work of (Govindarajan, 2010b). However, it shows a very interesting activity compared to that obtained on Anopheles stephensi larvae through the studies carried out on the leaves of Ajuga remota: 330 ppm in $24 \mathrm{hrs}$ and $290 \mathrm{ppm}$ in $48 \mathrm{hrs}$ (Preeti et al., 2004), as well as that carried out by Muema et al. (2016) in Kenya on larvae of Anopheles gambiae and Anopheles arabiensis with the methanolic extract of Agerantum conyzoides and gave $\mathrm{LC}_{50}=232.70 \mathrm{ppm}$ and $406.35 \mathrm{ppm}$ in $24 \mathrm{hrs}$ of treatment. Moreover, it should be mentioned that, apart from their traditional use as food, numerous studies (Adimonyemma et al., 2016; Gbadamosi et al., 2012) have proved a proven activity of Launaea taraxacifolia against microorganisms such as: Staphylococcus aureus, Escherichia coli, Klebsiella pneumonia, Candida albicans and Proteus spp.

In all the results presented, it can be deduced that, apart from its well-known nutritive properties, Launaea taraxacifolia possesses a very interesting larvicidal power with respect to Anopheles gambiae. The results of this study are encouraging in the direction of malaria eradication through anti-larval control using green chemistry. It is therefore necessary to continue this work in the interest of specifically identifying the compounds responsible for the larvicidal activity in this edible legume, in order to produce a bio-larvicide that is accessible to vulnerable populations.

\section{Conflict of interest statement}

Authors declare that they have no conflict of interest.

\section{Acknowledgement}

Authors thank Prof. Jacques Poupaert UCL/ Belgium for proofreading the English version of the manuscript and Razacky OSSE PhD, for their cooperation in entomological investigations. 


\section{References}

Adebisi, A.A., 2004. Launaea taraxacifolia (Willd.) Amin ex C. Jeffrey. In: PROTA 2: Vegetables/Légumes (Eds.: Grubben, G.J.H., Denton, O.A.). PROTA, Wageningen, Netherlands.

Adimonyemma, N.R., Chukwuma, O.M., Akachukwu, E.E., Iroka, F.C., 2016. Phytochemical analysis and antibacterial activity of Launaea taraxacifolia ethanolic leave extract. Sch. Acad. J. Biosci. 4(3A), 193-196.

Adinortey, M.B., Sarfo, J.K., Quayson, E.T., Weremfo, A., Adinortey, C.A., Ekloh, W., Ocran, J., 2012. Phytochemical screening, proximate and mineral composition of Launaea taraxacifolia leaves. Res. J. Med. Plants. 2, 171-179.

Ahouansou, C.A., Fagbohoun, L., Mèdégan Fagla, S.R., Tchètchè, J., Kotchoni, S., Gbaguidi, A.F., 2016. Phytochemical analysis, toxicity and larvicidal activity of extracts from Launaea taraxacifolia (Asteraceae) on Anopheles gambiae, a malaria vector. Int. J. Vector Borne Dis. 107, 130-138.

Aouinty, B., Oufara, S., Mellouki, F., Mahari, S., 2006. Évaluation préliminaire de l'activité larvicide des extraits aqueux des feuilles du ricin (Ricinus communis L.) et du bois de thuya (Tetraclinis articulata (Vahl) Mast.) sur les larves de quatre moustiques culicidés: Culex pipiens (Linné), Aedes caspius (Pallas), Culiseta longiareolata (Aitken) et Anopheles maculipennis (Meigen). Biotechnol. Agron. Soc. Environ. 10, 67-71.

Arawande, J.O., Amoo, I.A., Lajide, L., 2013. Chemical and phytochemical composition of wild lettuce Launaea taraxacifolia. J. Appl. Phytotechnol. Environ. Sanit. 2, 25-30.

Becker, N., 1998. The use of Bacillus thuringiensis subsp. israelensis (BTI) against mosquitoes, with special emphasis of the ecological impact. Israel. J. Entomol. XXXH, 63-69.

Chougourou, C.D., Dellouh, P.L., Agbaka, A., N'guessan, K.R., Gbénou, J.D., 2012. Toxicité et effets répulsifs de certaines huiles extraites des plantes locales Béninoises sur la mouche domestique Musca domestica L. (Diptera Muscidae). Journal of Applied Biosciences 55:3953- 3961.

Coosemans, M., Barutwanayo, M., Delacolette, C.H., 1992. Lutte anti-paludique intégrée dans une région rizicole au Burundi. Mém. Soc. Belg. Ent. 35, 97101.

Dansi, A., Vodouhe, R., Azokpota, P., Yedomonhan, H.,
Assogba, P., Adjatin, A., Loko, Y.L., DossouAminon, I., Akpagana, K., 2012. Diversity of the neglected and underutilized crop species of importance in Benin. Scient. World J. 2012, 932947.

Dickson, R.A., Annan, K., Fleischer, T.C., Amponsah I.K., Nsiah, K., Oteng, J.A., 2012. Phytochemical investigations and nutritive potential of eight selected plants from Ghana. J. Pharm. Nutr. Sci. 2, 172-177.

Djogbenou, L., Pasteur, N., Akogbeto, M., Weill, M., Chandre, F., 2011. Insecticide resistance in the Anopheles gambiae complex in Benin: A nationwide survey. Med. Vet. Entomol. 25, 256-67.

Edi, C.V., Koudou, B.G., Jones, C.M., Weetman, D., Ranson, H., 2012. Multiple-insecticide resistance in Anopheles gambiae mosquitoes, Southern Cote d'Ivoire. Emerg. Infect. Dis. 18, 1508-1511.

Fagbohoun, L., Gbaguidi, A.F., Ayédoun, A., Mathe, C., Moudachirou, M., Vieillescazes, C., 2014. Etudes ethnobotanique et phytochimique des plantes tinctoriales sources de colorants naturels et matériaux résineux traditionnels du Bénin dans le domaine artisanal (Ifangni/ Bénin). Ethnopharmacol. 52, 56-66.

Fagbohoun, L., Coffi, A., Ganfon, H., Medegan Fagla, S.R., Gbaguidi, A.F., Morel, G., Moudachirou, M., 2015. Variability of polyphenolic extracts from different oil palm trees and evaluation of their effect on Coelaenomenodera lameensis (Coleoptera, Chrysomelidae) larvae. Int. J. Biol. Chem. Sci. 9, 679-691.

Fillinger, U., Ndenga, B., Githeko, A., Lindsay, S.W., 2009. Integrated malaria vector control with microbial larvicides and insecticide-treated nets in western Kenya: A controlled trial. Bull. World Hlth. Organ. 87, 655-665.

Gbadamosi, I.T., Alia, A.E., Okolosi, O., 2012. In vitro antimicrobial activities and nutritional assessment of roots of ten Nigerian vegetables. New York Sci. J. 5, 234-240.

Gillies, M.T., Coetzee, M., 1987. A Supplement to the Anophelinae of Africa South of the Sahara. Publication of the South African Institute of Medical Research. pp.55-143.

Govindarajan, M., 2010a. Larvicidal efficacy of Ficus benghalensis L. plant leaf extracts against Culex quinquefasciatus Say, Aedes aegypti L. and Anopheles stephensi L. (Diptera: Culicidae). Eur. Rev. Med. Pharmacol. Sci. 14, 107-111.

Govindarajan, M., 2010b. Larvicidal and repellent 
activities of Sida acuta Burm F. (Malvaceae) against three important vector mosquitoes. Asian Pac. J. Trop. Med. 3(9), 691-695.

Harry, M., Rasplus, J.Y., Lachaise, D., 1994. La coévolution plantes-insectes': l'engrenage de deux enjeux génétiques. Biol. Espèces. 94, 4.

Houghton, P.J., Roman, A., 1998. Laboratory Hand Book for the Fractionation of Natural Extracts. Pharmacognosy Research Laboratories, Department of Pharmacy, King's College, London. 187p.

Komalamisra, N., Trongtokit, Y., Rongsriyam, Y., Apiwathnasorn, C., 2005. Screening for larvicidal activity in some Thai plants against four mosquito vector species. Southeast Asian J. Trop. Med. Public Health. 36, 1412-1422.

Koukoui, O., Agbangnan, P., Boucherie, S., Yovo, M., Nusse, O., Combettes, L., Sohounhloué, D., 2015. Phytochemical study and evaluation of cytotoxicity, antioxidant and hypolipidemic properties of Launaea taraxacifolia leaves extracts on cell lines HepG2 and PLB985. Amer. J. Plant Sci. 6, 17681779.

Muema, J.M., Njeru, S.N., Colombier, C., Marubu, R.M., 2016. Methanolic extract of Ageratum conyzoides exhibited toxicity and growth disruption activities against Anopheles gambiae sensu stricto and Anopheles arabiensis larvae. BMC Compl. Altern. Med. 16, 475.

Murugesan, S., Palani, G., Murugesan, S., Arivoli, S., Raveen, R., Tennyson, S., 2015. Mosquito larvicidal activity of Hyptis suaveolens (L.) Poit (Lamiaceae) aerial extracts against the filarial vector Culex quinquefasciatus Say (Diptera: Culicidae). J. Med. Plants Stud. 3(4), 1-5.

Nwane, P., Etang, J., Chouasmall, Yi, U.M., Toto, J.C., Koffi, A., Mimpfoundi, R., Simard, F., 2013. Multiple insecticide resistance mechanisms in Anopheles gambiae s.l. populations from Cameroon, Central Africa. Parasit. Vectors. 6, 41

OMS, 2016. Aide mémoire $\mathrm{N}^{\circ}$ 94. http://www.who.int/ mediacentre/factsheets/fs094/fr.

Owoeye, O., Femi-Akinlosotu, O.M., Adejuwon, S.A., 2015. Launaea taraxacifolia aqueous extract attenuates cisplatin-induced neurotoxicity by decreasing oxidative stress and neuronal cell death in rats. Arch. Bas. Appl. Med. 3, 71-78.

Preeti, S., Lalit, M., Srivastava, C.N., 2004. Larval susceptibility of Ajuga remota against Anopheline and Culicine mosquitos. Southeast Asian J. Trop. Med. Public Health. 35, 608-610.

WHO, 2005. Guidelines for Laboratory and Field Testing of Mosquito Larvicides, Geneva.

\section{How to cite this article:}

Ahouansou, C. A., Fagbohoun, L., Mèdégan Fagla S., Houngbèmè G. A., Kotchoni S., Gbaguidi, A. F., 2017. Inhibition effects of Elaeis oleifera (Arecaceae) and Launaea taraxacifolia (Asteraceae) on two genotypes of Anopheles gambiae larvae. Int. J. Curr. Res. Biosci. Plant Biol. 4(7), 39-46.

doi: https://doi.org/10.20546/ijcrbp.2017.407.005 